Article - Agriculture, Agribusiness and Biotechnology

\title{
Milk with Juçara (Euterpe edulis Martius) Pulp: Fermentation by $L$. reuteri LR92 and Reuterin Production in Situ
}

Maria Thereza Carlos Fernandes ${ }^{1 *}$

https://orcid.org/0000-0003-3285-2526

\section{Karla Bigetti Guergoletto ${ }^{1}$ \\ https://orcid.org/0000-0002-8285-2711}

Lycio Shinji Watanabe ${ }^{2}$

https://orcid.org/0000-0002-7049-9228

\author{
Suzana Lucy Nixdorf ${ }^{2}$ \\ https://orcid.org/0000-0002-6016-8329
}

\author{
Admilton Gonçalves de Oliveira ${ }^{3}$ \\ https://orcid.org/0000-0003-1556-5146 \\ Sandra Garcia ${ }^{1}$ \\ https://orcid.org/0000-0003-3704-9222
}

${ }^{1}$ State University of Londrina, Department of Food Science and Technology; Londrina, Brazil; ${ }^{2}$ State University of Londrina, Department of Chemistry; Londrina, Brazil; ${ }^{3}$ State University of Londrina Department of Microbiology; Londrina, Brazil.

Received: 2019.05.06; Accepted: 2020.03.27.

*Correspondence: thereza.fernandes@hotmail.com; Tel.: ++55 43 3371-5962 (M.T.C.F.)

HIGHLIGHTS

- Production of $0.43 \pm 0.01 \mathrm{mmol} \mathrm{L}^{-1}$ of reuterin was detected in the product.

- L. reuteri presented viability of $6.2 \log \mathrm{CFU} / \mathrm{mL}$ after 30 days of storage.

- After gastrointestinal simulation, the product presented 2.47 log CFU / mL of cells.

- Fermented milk with juçara pulp presented good sensory acceptance.

Abstract: This study aimed to develop and evaluate fermented milk by Lactobacillus reuteri LR92 with addition of juçara pulp (FMJ) and reuterin production in situ. The fermentation process was analyzed for 24 hours and the storage of FMJ for 30 days at $4{ }^{\circ} \mathrm{C}$. During the fermentation, there was consumption of $25 \%$ $(\mathrm{w} / \mathrm{v}$ ) of lactose and increase of 0.01 to $0.85 \%(\mathrm{w} / \mathrm{v}$ ) of lactic acid. The FMJ presented $0.43 \pm 0.01 \mathrm{mM}$ of reuterin, inhibiting Staphylococcus aureus strains under in vitro test. For the carbohydrates, the percentages $\left(\mathrm{g} .100 \mathrm{~g}^{-1}\right)$ found were $7.31 \pm 1.07 ; 9.19 \pm 0.82 ; 1.60 \pm 0.50$ and $0.08 \pm 0.00$ for sucrose, lactose, galactose and fructose respectively. The survival of $L$. reuteri, present in FMJ, was $2.47 \log \mathrm{CFU} / \mathrm{mL}$ after 6 hours of gastrointestinal simulation. In sensory analysis FMJ received a grade 7 for global acceptance indicating good acceptance of the product.

Keywords: functional food; lactic acid bacteria; gastrointestinal simulation; Euterpe edulis; antimicrobial; fermentative process.

\section{INTRODUCTION}

Fermentation is a traditional technique used for food production and preservation which provides foods with improvements in its safety, sensory, nutritional and functional attributes. Dairy products can be fermented by a diverse microbiota, and the use of probiotic cultures, such as Lactobacillus acidophilus, Lactobacillus casei and Lactobacillus reuteri, makes its functionality possible [1]. 
Lactobacillus reuteri (L. reuteri) belongs to the group of lactic acid bacteria (LAB). It is heterofermentative, has the certificate of "Qualified Presumption of Security" (QPS) by the European Food Safety Authority (EFSA) and is widely used in the pharmaceutical and food industry. Some strains of $L$. reuteri promote the inhibition of pathogenic microorganisms, it's has a modulating effect on the immune response, assists in gastrointestinal motility and intestinal microbiota balance, furthermore it also demonstrates clinical efficacy in reducing blood cholesterol [2]. This probiotic action of $L$. reuteri can be attributed to a combination of mechanisms such as the production of lactic acid, hydrogen peroxide, hydrolases and the ability of some strains to produce reuterin ( $\beta$-hydroxypropionaldehyde), among others [3].

Reuterin (3-HPA) is an antimicrobial produced on anaerobic conditions and in the presence of glycerol. This compound inhibits the growth of many Gram-positive and Gram-negative species, such as Escherichia coli, Salmonella enterica, Listeria monocytogenes and Staphylococcus aureus [4]. Because of the spectrum of action, reuterin has been proposed to improve food safety and quality by reducing the addition of chemical compounds.

In addition to the use of probiotic cultures, the expansion of the dairy market has led to the fusion of dairy products and fruit derivatives, creating hybrid products, improving aroma and flavor characteristics, and also the functionality of these products [5]. Thus, the use of typical Brazilian fruits, such as juçara, becomes an alternative for regional food consumption, which is recommended by the United Nations Food and Agriculture Organization (2008) [6].

The juçara palm (Euterpe edulis Martius) is widely distributed in the Atlantic Forest. The palm heart extracted from juçara is edible, and much appreciated by consumers. Illegal logging has occurred since the mid-1940s, and its peak in 1970 was motivated by the economic value of the product. Due to intense predatory exploitation and indiscriminate logging, the natural regeneration and conservation of juçara palm has been severely impaired [7]. The use of its fruit for human consumption has been proving to be a sustainable and economically viable form of exploitation because does not result in the death of the plant.

These globose fruits weigh about $1 \mathrm{~g}$ with a diameter of 1 to $1.5 \mathrm{~cm}$. The mesocarp is fleshy and very thin with the seed constituting $85 \%$ of the fruit [8]. Due to the similarities, the use of juçara palm fruit in the same way as açai, through the economic exploitation of the pulp, as a commercial alternative and for the sustainable management of the species, is an attractive option [9]. The fruit of the juçara palm is considered a "super fruit", rich in nutrients of high nutritional value. The antioxidant activity of these fruits, mainly by anthocyanins and phenolics [10], is constantly associated with the decrease of chronic diseases caused by oxidative stress [11]. In addition, in vitro intestinal simulation with juçara pulp demonstrated that the presence of this fruit increased the population of beneficial bacteria in the intestine, such as Bifidobacterium spp., in 24 hours of fermentation [12].

Therefore, the present work aims to evaluate the process of milk fermentation by L. reuteri LR92, for the development of fermented milk with addition of juçara pulp. It also aimed to evaluate the physicochemical, microbiological and sensorial properties of this formulated product, as well as to verify the production of reuterin in situ and antimicrobial activity against $S$. aureus strains.

\section{MATERIAL AND METHODS}

\section{Microorganisms}

The L. reuteri strain LR92 (Sacco DSM 26866-Cadorago, Italy) in lyophilized form was stored at $0.1 \%$ $(\mathrm{w} / \mathrm{v})$ concentration in reconstituted skimmed milk (RSMP) containing $18 \%(\mathrm{w} / \mathrm{v})$ solids at $-18{ }^{\circ} \mathrm{C}$ until use. The inoculum was activated twice for 24 hours at $37^{\circ} \mathrm{C}$ prior to inoculation.

The cultures of S. aureus ATCC 29231 and N315 (from the Microbial Biotechnology Laboratory of the State University of Londrina, Brazil) were kept in $40 \%$ (v/v) glycerol solution in liquid nitrogen and previously activated in Mueller-Hinton agar (Kasvi-Brazil) for $24 \mathrm{~h}$ at $37^{\circ} \mathrm{C}$.

\section{Chemical}

Glycerol (Química Moderna, Brazil), lactose, galactose, fructose and sucrose patterns (Sigma Aldrich, USA), Sodium hydroxide (Química Moderna, Brazil), monobasic sodium phosphate $\left(2 \mathrm{H}_{2} \mathrm{O}\right)$; (Química Moderna, Brazil), hydrochloric acid (Química Moderna-Brazil), tryptophan( Millipore, USA), acrolein (SigmaAldrich, USA), phosphate buffer, food grade glycerol (Arcolor, Brazil). Bile and enzymes: pancreatin (Porcine pancreas - Sigma-Aldrich, New Zealand) pepsin (swine gastric mucosa - Sigma-Aldrich , USA ), lipase (Rhizopus oryzae - Sigma-Aldrich, USA). 


\section{Juçara pulp}

The fruits of juçara were collected in the $2016^{\text {th }}$ season of palm trees produced at Bimini Farm (RolândiaPR, Brazil) and the pulp was obtained and pasteurized according to Guergoletto and coauthors [12]. The seeds were separated for planting and the pulp was frozen in fractions until its use.

\section{Evaluation of the fermentative process}

In order to determine the time required for the $\mathrm{pH}$ to reach the value of 4.5 (adapted from Langa and coauthors) [3] and to determine the cell growth profile, acid production and carbohydrate consumption by $L$. reuteri in the milk, a process fermentation was conducted.

For the production of the fermented milk, $18 \%(\mathrm{w} / \mathrm{v})$ of the skimmed milk powder (RSMP) (Molico $\AA$, Nestlé, São Paulo, Brazil) were reconstituted, and it was pasteurized at $95^{\circ} \mathrm{C}$ for 5 min and cooled in an ice bath at $37^{\circ} \mathrm{C}$. After that were added $100 \mathrm{mM}$ of food grade glycerol (Arcolor®, São Paulo, Brazil) and $1 \%$ $(\mathrm{v} / \mathrm{v})$ of active $L$. reuteri cells. The fermentation was carried out in sterilized glass containers, incubated at $37^{\circ} \mathrm{C}$ in anaerobic jar (Permution, Brazil) with anaerobiosis generator (Probac, Brazil) for 24 hours.

Every 4 hours, fermentation process (FP) samples were taken for analysis of cell viability, $\mathrm{pH}$, organic acids and carbohydrates.

\section{Production of fermented milk with addition of juçara pulp (FMJ)}

For the development of the fermented milk, RSMP was prepared and inoculated with L. reuteri LR92 as described in the item "Evaluation of the fermentative process" and incubated in an anaerobic jar at $37^{\circ} \mathrm{C}$ until $\mathrm{pH} 4.5$ (approximately $12 \mathrm{~h}$, previously determined during the fermentative process).

After the fermentation, $10 \%(\mathrm{w} / \mathrm{v})$ of sucrose (Camil, Brazil) and $5 \%(\mathrm{v} / \mathrm{v})$ of pasteurized juçara pulp were added to the fermented milk. Fermented milk (FM) with addition of $10 \%(\mathrm{w} / \mathrm{v})$ of sucrose was used for control.

\section{Storage}

The fermented milk (FM) and the fermented milk with juçara pulp (FMJ), were stored in glass containers at $4{ }^{\circ} \mathrm{C}$ for 30 days under anaerobic conditions (adapted from Langa and coauthors [3]), and analysis of cell viability, organic acids and carbohydrates were conducted every 15 days.

\section{Cell viability}

The $L$. reuteri viability was determined by the plate count method. The samples were homogenized by vortex, and decimal dilutions in peptone water $0.1 \%(\mathrm{w} / \mathrm{v})$ were conducted.

For the counting, $1.0 \mathrm{~mL}$ of each dilution was inoculated into Petri dish and subsequently the MRS medium (deMan, Rogosa and Sharpe) was added (pour plate method). The plates were incubated at $37^{\circ} \mathrm{C}$ for $48 \mathrm{~h}$ on anaerobiosis condition.

\section{Determination of $\mathrm{pH}$}

The $\mathrm{pH}$ was determined in a digital potentiometer (KASVI, Brazil).

\section{Determination of carbohydrates and organic acids}

\section{Extraction and preparation of the samples}

For the extraction of carbohydrates and organic acids from FP, FM and FMJ, $500 \mu \mathrm{L}$ of each sample were vortexed with $4500 \mu \mathrm{L}$ of ultrapure water (Milli-Q, Millipore, Billerica, MA, USA), then transferred to tubes and centrifuged at Ultra Centrifuge (Hitachi, Ibaraki, Japan) at $615,000 \mathrm{xg}$ for 15 minutes at $15^{\circ} \mathrm{C}$. The supernatants were filtered on $0.22 \mu \mathrm{m}$ polyvinylidene fluoride (PVDF) membranes (Millex®, Sigma-Aldrich, St. Louis, MO, USA) and stored in vials for the analysis.

\section{Determination of carbohydrates}

The carbohydrates: lactose, galactose, fructose and sucrose were determined in a high performance liquid chromatograph (HPLC) (LC 20A, Shimadzu, Kyoto, Japan) with refractive index detector (RID-10A, Shimadzu, Kyoto, Japan). The sample volume injected into the equipment was $20.0 \mu \mathrm{L}$, using only ultrapure water (Milli-Q®, Millipore, Billerica, MA, USA) as the mobile phase at a flow rate of $1.0 \mathrm{~mL} \mathrm{~min}^{-1}$ in a 
Fernandes, M.T.C.; et al.

chromatographic column Aminex HPX-87P cation exchange $(7.8 \times 300 \mathrm{~mm}$, Biorad, CA, USA) maintained at $80^{\circ} \mathrm{C}$. The data processing was performed using LC Solutions Software (Shimadzu, Kyoto, Japão) [13].

\section{Determination of organic acids}

The lactic and citric acids were determined by HPLC (LC 20A, Shimadzu, Kyoto, Japan) with refractive index detector $\left(\mathrm{RID}^{-1} \mathrm{OA}\right)$ and photodiode arrangement detector (SPD-M20A) also from Shimadzu. The injected sample volume was $20.0 \mu \mathrm{l}$, using a $25 \mathrm{mM}$ sodium phosphate buffer $(\mathrm{pH}=2.4)$ at the flow rate of $1.0 \mathrm{~mL} \mathrm{~min}^{-1}$ on a C18 chromatographic column (Shiseido CapCell Pak, 4, $6 \times 250 \mathrm{~mm}, 5 \mu$, Tokyo, Japan) maintained at $30{ }^{\circ} \mathrm{C}$. The detection was performed simultaneously on the refractive index $\left(\mathrm{RID}^{-1} \mathrm{OA}\right)$ and photodiode (SPD-M20A) detectors. The latter programmed for the fixed wavelength of $215 \mathrm{~nm}$ and in the scan mode of 200 to $400 \mathrm{~nm}$. Data collection and treatment were performed with the help of LCsolution software (Shimadzu, Kyoto, Japan) [14].

\section{Simulated gastrointestinal conditions}

The evaluation of $L$. reuteri survival in the FM and FMJ samples during gastrointestinal conditions was performed under similar conditions to gastric and enteric digestion in vitro [15]. First, $1 \mathrm{~g}$ of each sample was added to $10 \mathrm{~mL}$ of $0.5 \%$ saline solution by adjusting the $\mathrm{pH}$ between $2.3-2.6$ with $1 \mathrm{M} \mathrm{HCl}$ solution, adding the enzymes pepsin (swine gastric mucosa - Sigma-Aldrich St, Louis (MO, USA) and lipase (Rhizopus oryzae - Sigma-Aldrich, St. Louis, MO, USA) to achieve the concentration of $3 \mathrm{~g} \cdot \mathrm{L}^{-1}$ and $0.9 \mathrm{gL}^{-1}$, respectively (gastric phase). It was incubated for 2 hours at $37^{\circ} \mathrm{C}$ followed by plating. In the second phase (enteric 1) the $\mathrm{pH}$ of the samples was adjusted between 5.4 - 5.7 with alkaline solution (150 mL of $1 \mathrm{M} \mathrm{NaOH}$ with $14.0 \mathrm{~g}$ $\mathrm{NaPO}_{4} \mathrm{H}_{2} .2 \mathrm{H}_{2} \mathrm{O}$ ) adding bile and pancreatin (Porcine pancreas - Sigma -Aldrich, Auckland, New Zealand) at concentrations of $10.0 \mathrm{~g} \cdot \mathrm{L}^{-1}$ and $1.0 \mathrm{~g} \cdot \mathrm{L}^{-1}$, respectively, remaining at $37^{\circ} \mathrm{C}$ for 2 hours, followed by plating. The results were expressed in log CFU / $\mathrm{mL}$ of sample.

\section{Determination of reuterin}

For the determination of reuterin production, samples were homogenized and centrifuged $(1814 \times \mathrm{g}, 20$ $\min , 4^{\circ} \mathrm{C}$ ) and the supernatants were filtered (crude) on $0.22 \mu \mathrm{m}$ filter membranes (PVDF, Millipore, Merck). Thirty milliliters of crude supernatant were concentrated in a lyophilizer (Christ, Alpha 1-2) until the moisture was completely withdrawn, and then resuspended in distilled water to a concentration of 2.5 times (concentrate).

The crude and concentrated supernatants were used to quantify the presence of reuterin in triplicate by the photometric method cited by Tobajas and coauthors [16]. One milliliter of each supernatant (adjusted to $\mathrm{pH} 6.0$ with $0.1 \mathrm{M} \mathrm{NaOH}$ ) was added in $0.75 \mathrm{~mL}$ of $10 \mathrm{mM}$ tryptophan, dissolved in $0.05 \mathrm{M} \mathrm{HCl}$. After the addition of $3 \mathrm{~mL}$ of $37 \%(\mathrm{v} / \mathrm{v}) \mathrm{HCl}$, the mixture was incubated at $37{ }^{\circ} \mathrm{C}$ for 20 minutes and absorbance measured at $560 \mathrm{~nm}$. The analytical curve was obtained using acrolein (Sigma-Aldrich, St. Louis, MO, USA) in $50 \mathrm{mM}$ phosphate buffer, $\mathrm{pH} 7.5$, at concentrations of 0.05 to $6.00 \mathrm{mM}$.

\section{Inhibition test}

The crude and concentrated supernatants (adjusted to $\mathrm{pH} 6.0$ with $0.1 \mathrm{M} \mathrm{NaOH}$ ) were subjected to the inhibition tests against Staphylococcus aureus strains. For the test, $1 \mathrm{~mL}$ of the cultures of $S$. aureus ATCC 29231 and N315 in exponential phase at $8 \log$ CFU / mL (0.5 on the McFarland scale) were transferred to 20 $\mathrm{mL}$ of Mueller Hinton Agar (Kasvi-Brazil) medium $\left(37\right.$ to $40^{\circ} \mathrm{C}$ ) and poured into plates. After the solidification of the medium, the wells were made with standardized diameter $(10 \mathrm{~mm})$ and $50 \mu \mathrm{L}$ of the crude or concentrated supernatant was added. After 30 minutes of diffusion of the supernatants, the plates were incubated at $37^{\circ} \mathrm{C}$ for $24 \mathrm{~h}$. Inhibition halo reading was performed with caliper [17].

\section{Sensory evaluation}

After the approval by the Research Ethics Committee of the State University of Londrina (Process number 1684498), the acceptance of the FMJ was evaluated by 90 untrained tasters in the Laboratory of Sensory Evaluation of the Food Science and Technology Department. The attributes related to aroma, flavor, color, texture and overall acceptance of the product were evaluated using the hedonic scale of 9 points. The profile of the tasters (age, schooling, knowledge of the product) was determined through a questionnaire applied to them. All analyzes of hygienic and sanitary conditions were performed prior to sensory evaluation, ensuring product safety. 


\section{Statistical analysis}

All analysis were performed in genuine triplicate, using Variance Analysis (ANOVA) and Tukey's test for comparison at a $5 \%$ level of significance using the Statistica 10 program (StatSoft ${ }^{\circledR}$ Inc, USA, 2011).

\section{RESULTS AND DISCUSSION}

\section{Fermentation process}

The Figure 1 shows the results obtained during 24 hours of milk fermentation by L. reuteri. After 12 hours of fermentation (Figure 1a), the $\mathrm{pH}$ of the milk reached the desired value for FMJ production, presenting a viability of $7 \log$ CFU / mL. Hekmat and Reid [18] found a similar response, reporting L. reuteri counts of 7.3 $\log \mathrm{CFU} / \mathrm{mL}$ in fermented milk overnight at $37^{\circ} \mathrm{C}$. Regarding the $\mathrm{pH}$, there was a reduction from 6.5 to 4.0 during the 24 hours of fermentation.

The lactose content decreased from $9.91 \%$ to $7.43 \%$, mean values observed at $24 \mathrm{~h}$ of fermentation (Figure 1b), indicating a consumption of this carbohydrate by $L$. reuteri. The highest percentage of consumption (15\%) occurred in the interval between 12 and 16 hours, coinciding with a larger number of viable cells (Figure 1a). It was also observed that after consumption of lactose, the production of galactose started. Most of $L$. reuteri strains possess the enzyme $\beta$-galactosidase [19] responsible for the hydrolysis of lactose, releasing the monosaccharides glucose and galactose.

Figure $1 \mathrm{c}$ shows the results of the production of lactic and citric acids during $24 \mathrm{~h}$ period of fermentation. A marked increase in the concentration of lactic acid concomitant to the reduction of $\mathrm{pH}$ was observed, being initially $0.01 \%(\mathrm{pH}=6.47)$ and at the end of $24 \mathrm{~h} 0.85 \%(\mathrm{pH}=4.10$ Figure $1 \mathrm{a})$. In relation to the citric acid concentration, it remained stable during fermentation, with a maximum value of $0.24 \%$ (Figure 1c). This result is consistent with that found by Østlie and coauthors [20] who obtained $0.22 \%$ of citric acid in milk fermented by L. reuteri SD 2112. 

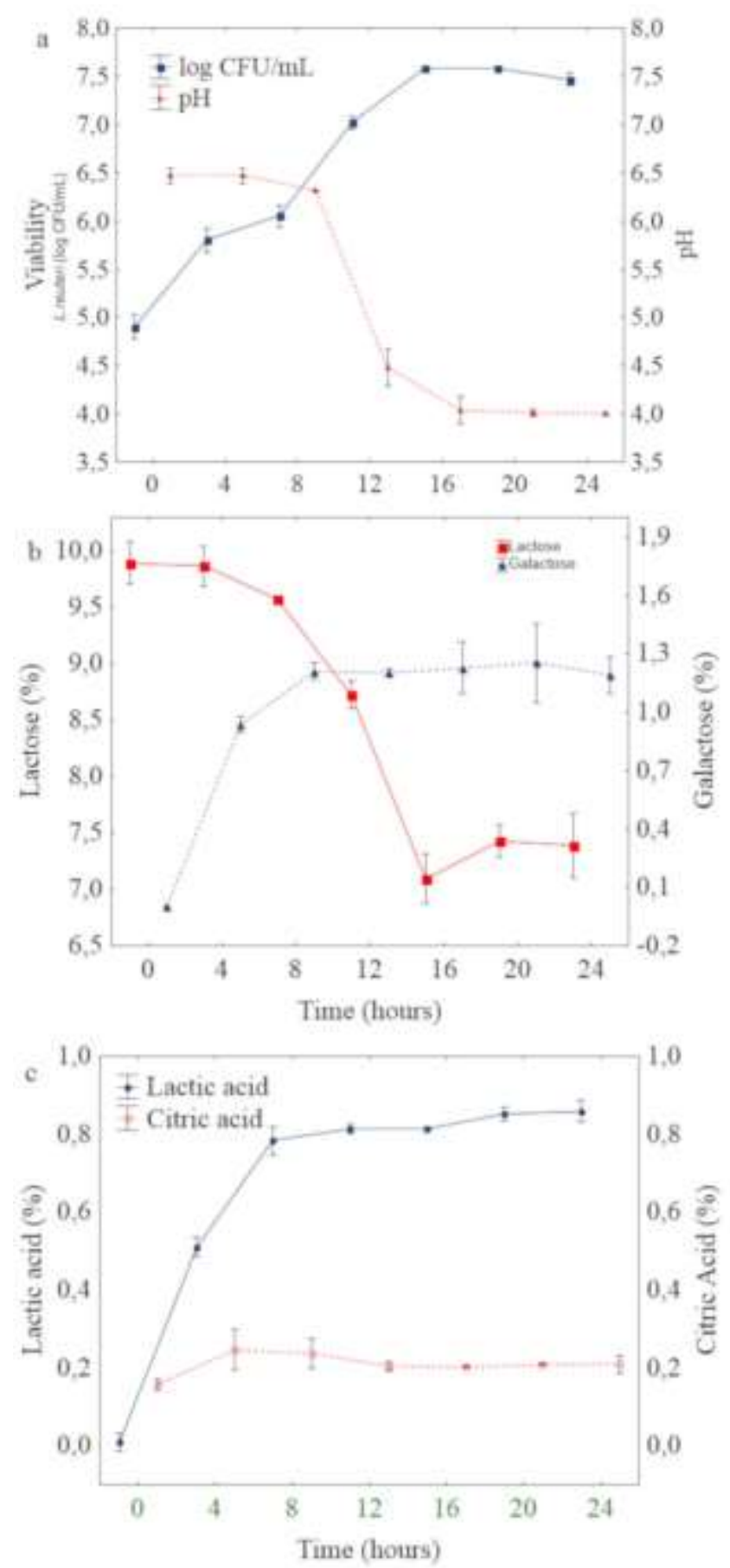

Figure 1. Fermentative process of $L$. reuteri in reconstitute skim milk for $24 \mathrm{~h}$ : (a) $L$. reuteri viability and $\mathrm{pH}$ values. (b) Lactose and galactose concentration (c) production of organic acids.

\section{Storage}

The product FMJ and control (FM) were stored for 30 days at $4{ }^{\circ} \mathrm{C}$. The results (Table 1) demonstrate that the addition of juçara pulp did not negatively interfere in any of the evaluated parameters, during the time studied, when compared to FM. A 1 log reduction in viability of $L$. reuteri was observed in FMJ and FM during the 30 days of storage. These results were similar to those of Hekmat and Reid [18] and Langa and coauthors [3] where a reduction of $0.83 \log \mathrm{CFU} / \mathrm{mL}$ and up to $1.93 \log \mathrm{CFU} / \mathrm{mL}$ of $L$. reuteri was observed in the yogurts stored at $4{ }^{\circ} \mathrm{C}$ for 28 days. 
Table 1. Parameters evaluated on days 1,15 and 30 of storage at $4{ }^{\circ} \mathrm{C}$ for fermented milk (FM) and fermented milk with juçara pulp (FMJ).

\begin{tabular}{|c|c|c|c|c|c|c|}
\hline & & & Days & & & \\
\hline & 1 & & 15 & & 30 & \\
\hline & FM & FMJ & FM & FMJ & FM & FMJ \\
\hline $\begin{array}{l}\text { Cell } \\
\text { Viability } \\
\text { (logCFU/mL) }\end{array}$ & $7.00^{a} \pm 0.01$ & $7.00^{a} \pm 0.01$ & $6.70^{a} \pm 0.05$ & $6.8^{a} \pm 0.01$ & $6.0^{b} \pm 0.01$ & $6.20^{b} \pm 0.20$ \\
\hline $\mathrm{pH}$ & $4.50^{c} \pm 0.02$ & $4.70^{\mathrm{a}} \pm 0.00$ & $4.45^{d} \pm 0.03$ & $4.60^{b} \pm 0.05$ & $4.40^{d} \pm 0.03$ & $4.50^{c} \pm 0.1$ \\
\hline Sucrose g. $100 \mathrm{~g}^{-1}$ & $8.20^{b, c} \pm 0.83$ & $11.90^{a} \pm 0.71$ & $7.30^{b, c} \pm 0.80$ & $8.85^{b} \pm 0.67$ & $6.10^{c} \pm 0.02$ & $7.31^{b, c} \pm 1.07$ \\
\hline Lactose g. $100 \mathrm{~g}^{-1}$ & $9.87^{a} \pm 1.21$ & $8.68^{a} \pm 2.86$ & $10.17^{a} \pm 2.40$ & $9.38^{a} \pm 0.41$ & $9.94^{\mathrm{a}} \pm 1.60$ & $9.19^{a} \pm 0.82$ \\
\hline Galactose g.100g-1 & $1.20^{\mathrm{a}} \pm 0.05$ & $1.43^{a} \pm 0.60$ & $1.60^{\mathrm{a}} \pm 0.50$ & $1.65^{a} \pm 0.11$ & $1.32^{\mathrm{a}} \pm 0.00$ & $1.60^{\mathrm{a}} \pm 0.50$ \\
\hline Fructose g. $100 \mathrm{~g}^{-1}$ & ND & $0.10^{\mathrm{a}} \pm 0.02$ & ND & $0.08^{a} \pm 0.00$ & ND & $0.08^{a} \pm 0.00$ \\
\hline Lactic acid g. $100 \mathrm{~g}^{-1}$ & $1.13^{a} \pm 0.01$ & $1.04^{a} \pm 0.08$ & $0,89^{b ; c} \pm 0.1$ & $1.11^{a} \pm 0.04$ & $0.77^{c} \pm 0.04$ & $0,86^{b} \pm 0.03$ \\
\hline Citric acid g. $100 \mathrm{~g}^{-1}$ & $0.22^{a} \pm 0.00$ & $0.30^{a} \pm 0.13$ & $0.29^{a} \pm 0.04$ & $0.27^{a} \pm 0.08$ & $0.22^{\mathrm{a}} \pm 0.02$ & $0.22^{a} \pm 0.02$ \\
\hline
\end{tabular}

ND: not detected.

Means with different letters on the same line differ significantly $(p<0.05)$.

Regarding carbohydrates (Table 1) the lactose values quantified in FMJ and FM are close to that described by Czaja and coauthors [21] for commercial yoghurts, from 6 to $9 \%$ lactose. These values are higher than the content of this sugar presented in fresh milk (close to 4.5\%) [22]. The increase of lactose can be justified by the supplementation of solids carried out in the present study. Galactose and sucrose were also detected, the presence of sucrose being due to the addition of $10 \%(\mathrm{w} / \mathrm{v})$ in the preparation of the product. The FMJ presented higher values of sucrose and the presence of fructose, because the juçara fruit contains these carbohydrates in the proportion of $4.62 \%$ on a wet basis [23]. During storage, sucrose concentrations were statistically reduced, possibly indicating that, even at refrigeration temperatures, this carbohydrate was metabolized by L. reuteri.

\section{Simulation of gastrointestinal conditions}

In this study both FMJ and FM, immediately after fermentation had $7 \log C F U / m L$ of $L$. reuteri and were submitted to the gastric simulation test (Figure 2). In the gastric phase (pH between 2.3 and 2.6), a decrease of one log cycle was observed in the counts (6 log of CFU / mL) from L. reuteri to FM, while for FMJ the counts were $4.7 \mathrm{log}$ of CFU / mL. These survivals are superior to those found by Champagne and Gardner [24], that reported at the end of the gastric phase a survival of $2.7 \log$ CFU / $\mathrm{mL}$ for L. reuteri culture in concentrated fruit juice (mixture of pineapple, apple, pear, grape, passion fruit). The acid tolerance of bacteria is important not only to overcome the gastric phase during digestion but also as a prerequisite for its use as a probiotic food, allowing the microorganisms to survive longer in acidic foods such as yogurt and fermented milk [25]. 


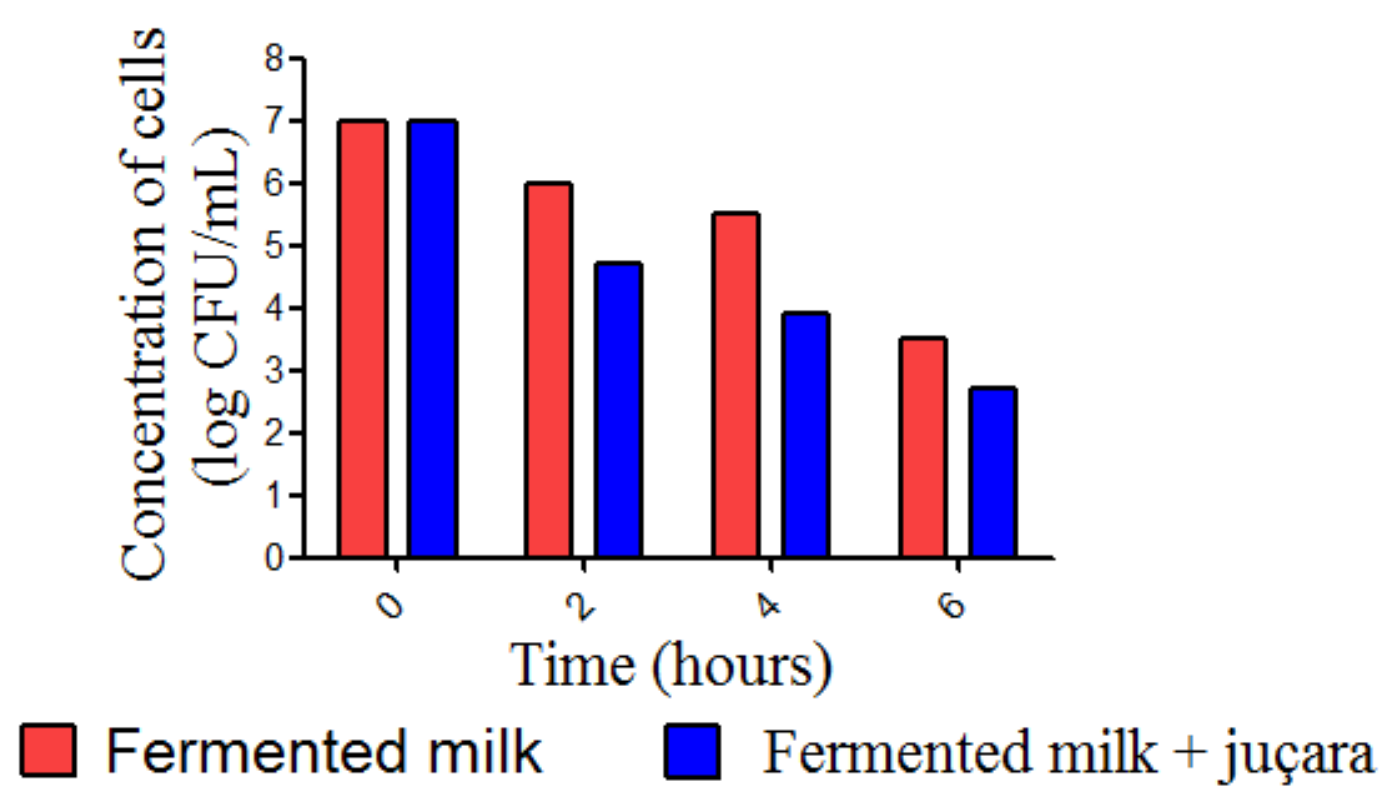

Figure 2. Cell survival of $L$. reuteri in fermented milk with sucrose and fermented milk with juçara pulp and sucrose at the $1^{\text {st }}$ day and after each step of the gastrointestinal simulation.

The number of viable cells at the end of all simulation steps for FM and FMJ was 3.47 log CFU / $\mathrm{mL}$ and $2.47 \log$ CFU / mL, respectively. Bedani and coauthors [15] also observed that the addition of fruit pulps to yogurt may be involved in reducing probiotic survival in simulated gastrointestinal conditions. Although fruit pulp did not affect the probiotic viability in FMJ during storage, the chemical composition of juçara pulp, as organic acids and phenolic compounds commonly present in this fruit, might have been involved in the decreased probiotic survival under the simulated gastrointestinal conditions [15-26]. In addition, further studies are needed to investigate which constituents of fruit pulps might influence upon the resistance of probiotic strains during the passage through the gastrointestinal tract.

The survival of $L$. reuteri after 6 hours of simulation in FM and FMJ was lower than that described by Wang and coauthors (6.72 log CFU / mL) in MRS broth. This difference may be related to the different matrices and strains used in the experiments. The verification of the tolerance of the microorganisms at the end of the simulation in the gastrointestinal conditions helps to select an adequate food matrix. The best processing conditions that can guarantee the survival of the microorganism of interest could also be evaluated [27].

\section{Reuterin inhibition and quantitation assay}

To verify, in the formulated product, the production of reuterin by L. reuteri and its action in vitro to inhibit $S$. aureus, were used the FMJ and FM supernatants crude and 2.5 fold concentred. The results are presented in Table 2.

The 2.5-fold concentrates of the both supernatants (Table 2) presented antimicrobial effect for both strains tested: S. aureus ATCC 29231 and N315 (multiresistant). O'Keeffe and Hill [28] pointed out in their studies that among the microorganisms of public health importance which are inhibited by reuterin, those of the genus Staphylococcus are included, that is in agreement with the results obtained in the present study. In addition to Staphylococcus spp inhibition, L. reuteri growth under conditions compatible with reuterin production in dairy products may reach inhibitory concentrations against a variety of pathogenic, Gramnegative, and Gram-positive deteriorating bacteria [29]. 
Table 2. Measures of the inhibition halo and quantification of reuterin from fermented milk extracts and fermented milk extracts with addition of juçara pulp (crude and concentrated 2.5 - fold).

\begin{tabular}{lccc}
\hline Extracts & \multicolumn{2}{c}{ Inhibition halos $(\mathrm{mm})$} & $\begin{array}{c}\text { Concentration of } \\
\text { reuterin }\left(\mathrm{mmol} \mathrm{L}^{-1}\right)\end{array}$ \\
\hline & $\begin{array}{c}\text { S. aureus ATCC } \\
29231\end{array}$ & $\begin{array}{c}\text { S. aureus } \\
\mathrm{N} 315\end{array}$ \\
\hline \multicolumn{4}{c}{ JFM } \\
\hline Crude & non detected & non detected & $0.32 \pm 0.02$ \\
$2.5 \mathrm{x}$ & $8 \mathrm{~mm} \pm 0.00$ & $6 \mathrm{~mm} \pm 0.00$ & $0.43 \pm 0.01$ \\
\hline \multicolumn{4}{c}{ FM } \\
\hline Crude & non detected & non detected & $0.28 \pm 0.02$ \\
\hline Concentrated & $8.2 \pm 0.00$ & $\begin{array}{c}4.7 \mathrm{~mm} \pm \\
0.00\end{array}$ & $0.40 \pm 0.05$ \\
\hline
\end{tabular}

Silva and coauthors [17] testing the antimicrobial effect of $L$. reuteri ATCC 1428 supernatant describes a $4.3 \mathrm{~mm}$ inhibition halo for $S$. aureus, other microorganisms such as Bacillus cereus, E. coli, Proteus vulgaris and Vibrio cholerae, were also inhibited in this study. Langa and coauthors [29] also described the inhibitory effect of reuterin against $S$. aureus strains, which in this case acted as bacteriostatic after 4 hours and as bactericidal after 24 hours at $37^{\circ} \mathrm{C}$.

The quantification of reuterin by the indirect method through the acrolein curve showed a concentration of $0.32 \pm 0.02 \mathrm{mM}$ and $0.28 \pm 0.02 \mathrm{mM}$ for the JFM and FM crude supernatants respectively, and $0.43 \pm 0.01$ $\mathrm{mM}(\mathrm{JFM})$ and $0.40 \pm 0.05$ (FM) for the concentrated supernatants (2.5 times). Langa and coauthors [3] obtained results of reuterin concentration between 0.21 and $0.75 \mathrm{mM}$ for the different strains used in yogurt produced with $100 \mathrm{mM}$ of glycerol, under similar conditions to the present work. Ortiz-Rivera and coauthors [4] presented higher concentrations of reuterin in situ in fermented milk compared to our study. However, the same authors reported that $S$. aureus presented resistance up to $1.5 \mathrm{mM}$ of reuterin while in the present study the concentration of $0.40 \pm 0.05 \mathrm{mM}$ was sufficient to inhibit both $S$. aureus strains tested.

The differences in the reuterin produced could be caused by differences in the L. reuteri strain, $\mathrm{pH}$, biomass concentration, medium composition, oxygen concentration, cell age and incubation time [30].

\section{Sensory Evaluation}

Figure 3 shows the average scores of each attribute obtained in the sensorial analysis. The average acceptance of color parameter was $7.4 \pm 1.3$ and $57 \%$ of the tasters considered this attribute to be "like very much" and "like extremely". The flavor and the aroma attributes also received an average of $7.4 \pm 1.2$ a scale of nine where $50 \%$ and $61 \%$, respectively, rated these attributes as "like very much".

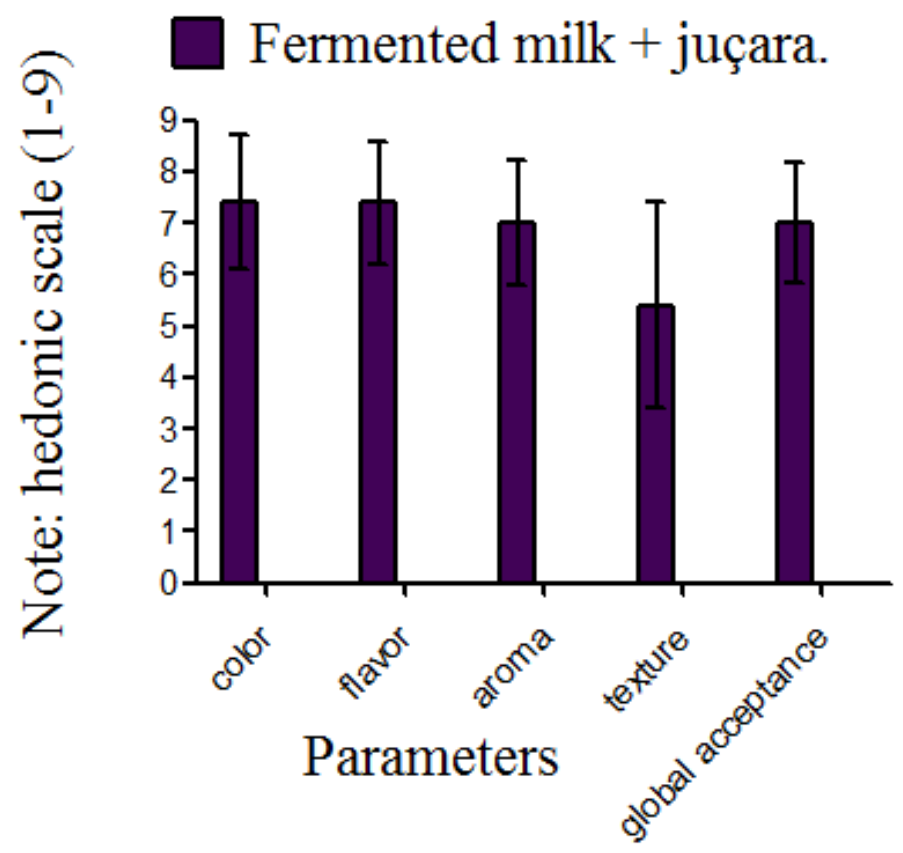


Figure 3. Evaluation of the sensory attributes (scale of 1-9) of fermented milk with addition of juçara pulp and sucrose.

The texture obtained the lowest score in this study. According to Champagne and coauthors [31] in the development of yogurt containing $L$. reuteri, sensorial problems were observed due to the formation of gas bubbles and syneresis, related to the heterofermentative metabolism of the microorganism. However, the same author observed that in the industrial scale productions, for this type of drink, the product will be pumped and mixed, thus minimizing these problems, an alternative that could be applied to our product [31].

The overall acceptance received an average of $7.0 \pm 1.1$, a similar mean was attributed to commercial fermented milks tested by Medeiros and coauthors [32] the three brands tested received respectively grades $6.8 \pm 1.6 ; 7.2 \pm 1.8$ and $6.4 \pm 1.5$. The acceptance values obtained in this work indicate that the product developed is in agreement with those found commercial $97 \%$ consume fermented products and $63 \%$ consume them moderately to frequently. In contrast, only $20 \%$ of the tasters knew or had consumed juçara, showing the economic potential of this fruit, despite the lack of knowledge of the population.

\section{CONCLUSION}

L. reuteri fermented milk with the addition of juçara pulp presented physicochemical characteristics similar to those of commercially available fermented milks, as well as maintaining a satisfactory number of viable probiotic cells during 30 days of storage. This product also exhibited antimicrobial activity against $S$. aureus, which can be attributed to the production of reuterin. In addition, fermented milk with juçara pulp was well accepted by potential consumers, indicating that this unexplored fruit can be applied to the development of a functional product, combining benefits and contributing to the preservation of the species.

Funding: This study was financed in part by the Coordenação de Aperfeiçoamento de Pessoal de Nível Superior Brasil (CAPES) - Finance Code 001", CNPq the financial assistance to the student Maria Thereza Carlos Fernandes and the Araucaria Foundation Technical Assistance Grant for the Lycio Shinji Watanabe

Acknowledgments: To Daniel Steidle and his family for the donation of juçara fruits.

Conflicts of Interest: The authors declare no conflict of interest.

\section{REFERENCES}

1. Macori G, Cotter PD. Novel insights into the microbiology of fermented dairy foods. Curr Opin Biotechnol. 2018 Feb;49(1):172-8.

2. Jones ML, Martoni CJ, Prakash S. Cholesterol lowering and inhibition of sterol absorption by Lactobacillus reuteri NCIMB 30242: a randomized controlled trial. Eur J Clin Nutr. 2012 Nov;66(11):1234-41.

3. Langa, S, Landete JM, Martín-Cabrejas I, Rodríguez E, Arqués JL, Medina M. In situ reuterin production by Lactobacillus reuteri in dairy products. Food Control. 2013 Sept;33(1):200-6.

4. Ortiz-Rivera Y, Sánchez-Vega R, Gutiérrez-Méndez N, León-Félix J, Acosta-Muñiz C, Sepulveda DR. Production of reuterin in a fermented milk product by Lactobacillus reuteri: Inhibition of pathogens, spoilage microorganisms, and lactic acid bacteria. J Dairy Sci. 2017 Jun;100(6):4258-68.

5. Barat A, Ozcan T. Growth of probiotic bacteria and characteristics of fermented milk containing fruit matrices. Int $\mathrm{J}$ Dairy Technol. 2018 Mar;71(1):120-9.

6. Food and Agriculture Organization. Climate-Smart Agriculture Sourcebook. Sourcebook on Climate-Smart Agriculture, Forestry and Fisheries. [Internet] 2008. [updated 2018 Feb 11; cited 2018 Feb 11]. Available from: http://www.fao.org/docrep/018/i3325e/i3325e00.htm.

7. Schulz M, da Silva GCB, Gonzaga LV, Oliveira Costa AC, Fett R. Juçara fruit ( Euterpe edulis Mart.): Sustainable exploitation of a source of bioactive compounds. Food Res. Int. 2016 Nov;89(1):14-26.

8. Bicudo MOP, Ribani RH, Beta T. Anthocyanins, phenolic acids and antioxidant properties of juçara fruits (Euterpe edulis M.) along the on-tree ripening process. Plant Foods for Hum. Nutr. 2014 Jun;69(2):142-7.

9. Cerisola CM, Antunes AZ, Port-Carvalho M. Consumo de frutos de Euterpe edulis Martius (Arecaceae) por vertebrados no Parque Estadual Alberto Löfgren, São Paulo, Sudeste do Brasil. Rev. do Inst. Florestal e IF Série Registros. 2007 Jul;31(1):167-71.

10. Schulz M, Borges GDC, Gonzaga LV, Seraglio SKT, Olivo IS, Azevedo MS; et al. Chemical composition, bioactive compounds and antioxidant capacity of juçara fruit (Euterpe edulis Martius) during ripening. Food Res. Int. 2015 Nov;77(2):125-31.

11. Manach C, Scalbert A, Morand C, Jimenez L. Polyphenols: Food sources and Bioavailability. Am J Clin Nutr. 2014 May;79(5):727-47. 
12. Guergoletto, K.B.; Costabile, A.; Flores, G.; Garcia, S.; Gibson, G.R. In vitro fermentation of juçara pulp (Euterpe edulis) by human colonic microbiota. Food Chemistry. 2016 April;196(1):251-8.

13. Pauli, E.D.; Cristiano, V.; Nixdorf, L. Method for Determination of Carbohydrates Employed in the Selection of Adulterations in coffee. Quím. Nova. 2011 Jan;34(4):689-94.

14. Reuter WM. Analysis of organic acids in fruit juices by HPLC and UV detection: Aplication note. Perkinelmer. [Internet]2015. [updated 2018 Feb 12; cited 2018 Feb 12]. Available from: https://www.perkinelmer.com/labsolutions/resources/docs/APP_Analysis-of-Organic-Acids-in-Fruit-Juices-by-HPLC-and-UV-Detection.

15. Bedani R, Vieira ADS, Rossi EA, Saad SMI. Tropical fruit pulps decreased probiotic survival to in vitro gastrointestinal stress in synbiotic soy yoghurt with okara during storage. LWT. 2014 Mar;55(2):436-43.

16. Tobajas M. Mohedano AF, Casas JA, Rodrígues JJ. A kinetic study of reuterin production by Lactobacillus reuteri PRO 137 in resting cells. Biochem. Eng. J. 2007 Dec;35(1):218-25.

17. Silva HS, Ramos RJ, Cirolin A, Miotto M, Bassegio AM, Vieira CRW. Antimicrobial activity of Lactobacillus reuteri against bacteria of nourishment concern. Rev. Inst. Adolfo Lutz. 2010 Dec;69(4):584-7.

18. Hekmat S, Reid G. Survival of Lactobacillus reuteri RC-14 and Lactobacillus rhamnosus GR-1 in milk.J. Food. Sci. Technol. 2007 Mar;42(1):615-9.

19. Splechtna B, Nguyen TH, Steinböck M, Kulbe KD, Lorenz W. Haltrich, D. Production of prebiotic galactooligosaccharides from lactose using $\beta$-galactosidases from Lactobacillus reuteri. J. Agric Food Chem. 2006 Jul; 54(14)4999-5006.

20. Ostlie HM, Helland MH, Narvhus JA. Growth and metabolism of selected strains of probiotic bacteria in milk and water-based cereal puddings. Int Dairy J. 2003 Oct;14(1-2):957-65.

21. Czaja T,Baranowska M,Mazurek S, Szostak R. Determination of nutritional parameters of yoghurts by FT Raman spectroscopy. Spectrochim Acta A Mol Biomol Spectrosc. 2018 Fev;5(1):413-7.

22. Uduwerella G, Chandrapala J. Preconcentration of yoghurt base by ultrafiltration for reduction in acid whey generation during Greek yoghurt manufacturing. Int J Dairy Technol. 2017 April;71(1):71-80.

23. Santana AA, Cano-Higuita DM, de Oliveira RA, Telis VRN. Influence of different combinations of wall materials on the microencapsulation of jussara pulp (Euterpe edulis ) by spray drying. Food Chemistry. 2016 May;212(1): 1-9.

24. Champagne CP, Gardner NJ. Effect of storage in a fruit drink on subsequent survival of probiotic lactobacilli to gastro-intestinal stresses. Food Res Int .2008 Mar;41(5):539-43.

25. Bertazzonii E, Benini A, Marzotto M, Sbarbati A, Ruzzenente O, Ferrario R, et al. Assessment of novel probiotic Lactobacillus casei strains for the production of functional dairy foods. Int Dairy J. 2004 Aug;14(8):723-36.

26. Espírito Santo AP, Perego P, Converti A, Oliveira MN. Influence of food matrices on probiotic viability-A review focusing on the fruity bases. Trends Food Sci Technol. $2011 \mathrm{Jul} ; 22(7): 377-85$.

27. Wang CY, Lin PR, Ng CC, Shyu YT. Probiotic properties of Lactobacillus strains isolated from the feces of breastfed infants and Taiwanese pickled cabbage. Anaerobe. 2010 Oct;16(6):578-85.

28. O'Keeffe T, Hill C. Bacteriocins Potential in Foods Preservation. In: Batt C, editor Encyclopedia of Food Microbiology. 2st Edition. New York: Elsevier; 2014. p. 183-97.

29. Langa S, Martín-Cabrejas I, Montiel R, Landete JM, Medina M, Arqués JL. Short communication: Combined antimicrobial activity of reuterin and diacetyl against foodborne pathogens. J Dairy Sci. 2014 Oct;97(10): 6116-21.

30. Stevens M, Vollenweider S, Lacroix C, Zurich E. The potential of reuterin produced by Lactobacillus reuteri as a broad spectrum preservative in food. In: Lacroix C, editor. Protective Cultures, Antimicrobial Metabolites and Bacteriophages for Food and Beverage Biopreservation. Zurich. Woodhead Publishing; 2011. p. 129-60.

31. Champagne CP, Raymond Y, Guertin N, Martoni CJ, Jones ML. Growth of Lactobacillus reuteri NCIMB 30242 during yogurt fermentation and bile salt hydrolysis activity in the product. Dairy Sci Technol. 2016 Sept;96(1): 17384.

32. Medeiros EJL, Lima ARC, Moura MD, De Moreira RT. Fermented milk trademark: a study of acceptance and correlation with pH and acidity. J. of Candido Tostes Dairy Inst. 2011 May, 66(381), 46-50.

2020 by the authors. Submitted for possible open access publication under the terms and conditions of the Creative Commons Attribution (CC BY NC) license (https://creativecommons.org/licenses/by-nc/4.0/). 